\title{
Extreme weather events related to climate change: widespread flooding in Iran, March-April 2019
}

\author{
Farahnaz Fazel-Rastgar ${ }^{1}$
}

Received: 13 July 2020 / Accepted: 25 November 2020 / Published online: 7 December 2020

(c) Springer Nature Switzerland AG 2020

\begin{abstract}
This study investigates the extreme weather pattern accompanying the widespread flash flooding in unpredicted areas during mid-March to April of 2019 in Iran. During this time, the active weather frontal system with heavy and insistent rainfalls drenched Iran (mostly north, west and southern), Iraq and Turkey (eastern part). The climatological mean and anomalies of the meteorological datasets from the National Centers for Environmental Prediction (NCEP) reanalysis model are examined, and synoptic and dynamical patterns are compared. The anomaly weather maps are created for different parameters to show the abnormal features during the study period (months of March and April 2019) presenting significant differences from the thirty-year climate normals of the period 1981-2010. This research shows an intensified pressure gradient, strong vertical motion and strengthened $500 \mathrm{hPa}$ mid-tropospheric westerly currents during the study period. The relative humidity at $850 \mathrm{hPa}$ shows on average $\sim 4-11 \%$ higher values than the climate normal. The surface wind vector analysis reveals the intensified south flows originated from Oman sea and the Indian Ocean providing rather warmer and wet air mass encounters with an abnormal regional colder surface air mass. Upper level wind vectors at $250 \mathrm{hPa}$ and vertical profile of the meridional wind anomalies exhibit a wavy jet pattern compared to the climate normal structure along with the significant vertical meridional wind shear as the sign of climate change. These abnormal atmospheric changes can contribute to forming extreme weather development over the study area during the study period. Also, understanding the recent extreme atmospheric changes in the study area may contribute to a better future forecast when such floods may happen again.
\end{abstract}

Keywords Flood $\cdot$ Climate change $\cdot$ Iran $\cdot$ Abnormal weather $\cdot$ Meridional wind anomaly

\section{Introduction}

Climate change impacts on the global average temperature increase and both human activities (i.e., produced greenhouse gases) and natural extreme weather are supposed to be contributing to this increase. Polar ice is declining, and global average sea level is rising [18]. Drought, water shortage, extreme weather, storm intensification and flooding are currently more common across the world. Recent studies show that climate change can be linked to different weather anomalies such as temperature fluctuations both below and above long-term mean, rather colder winters, summer extreme heat waves, lack of rainfalls, intensive storms and flooding $[6,10-12,14,21,30,34,35]$. Climate change causes changes in the intensity, frequency, spatial range and duration of weather and climate extremes and can lead into unprecedented extremes. The extremes changes can also be directly linked to changes in climate mean values [32]. Also, rather warmer atmosphere can be associated with the hydrological changes and can cause an increase in the intensity and the frequency of the regional flooding cases $[3,9,29]$. Local flash floods are disasters, which are not well known [17]. So, the hydrogeomorphic processes

Farahnaz Fazel-Rastgar, ffazelrastgar@gmail.com | ${ }^{1}$ York University, Toronto, Canada. 
of the floods are controlled by the atmosphere. Hydrology and local geomorphology are not well understood which sometimes leads to a very uncertain risk management and early warnings $[7,8]$. Consequently, every flood event analysis is very important. So, understanding of the floods as a weather-related phenomenon can be a key factor to adapt to climate change to reduce the flash floods negative impacts. In the Middle East and North Africa (MENA), climate change is more common and is anticipated to be more problematic $[5,20,22,27,28]$. Besides, the recent research shows that the areas located in MENA region are expected to increase in temperature at around 1.5 times faster rather than the mean global temperature $[1,15]$. Iran as a part of the MENA locates between $25-40^{\circ} \mathrm{N}$ and $45-63^{\circ}$ covering an area of about $1,648,000 \mathrm{~km}^{2}$. Iran has different climate zones covering approximately an area around $35.5 \%$ hyper-arid, $29.2 \%$ arid, $20.1 \%$ semi-arid, $5 \%$ Mediterranean, and $10 \%$ wet in the cold mountainous regions and the southern Caspian Sea coastal regions of its total areas [2,31]. Iran has faced human-induced climate change problems such as droughts, dust storms and severe floods both in the event severity and the occurrence frequency. For example, the Caspian Sea coastal areas flooding, with the worst one happening on August 2001 in Golestan province with 247 killed people [17, 23, $33,36]$ and recent deadly flash floods which affected 25 out of 31 provinces (83.8\%) in mid-March to April of 2019. At this time, the active frontal system with heavy and insistent rainfalls drenched Iran (mostly north, west and southern), Iraq and Turkey (eastern part). The heavy rainfall events caused several devastating flooding in three-quarters of Iran's provinces including Golestan, Mazandaran, Fars, Lorestan and Chaharmahal and Bakhtiari and 10 million people were affected and around two million people were severely affected and half of them were children [25]. Also, some rural regions of Basra, Ninevah, Wasit and Babil provinces in Iraq suffered from flash floods [24].

This study investigates the anomalies in meteorological parameters in comparison with the normal mean climatological values for months of March and April 2019 over Iran. This work aims to see the possibility of climate variability role for this individual weather extreme pattern that led to flooding events in Iran.

\section{The flood statistics in Iran and some characteristic of the widespread flooding of March-April 2019}

Flood is one of the frequent common disasters which has been increased both in frequency and severity in Iran. Based on the Iranian Forestry Organization report, the number of flooding events in Iran has been considerably increased since 1951-2017 with a maximum of 2097 during a period of 1991-2000 Fig. 1. Climate change is one of the important anthropogenic causes which can impact on the flood pattern and dynamics. The flooding events of March-April 2019 in Iran constitute unprecedented flooding cases which can be related to climate change. The heavy rainfall events covered three major periods including 17-19 March, mostly over west of Golestan province and east of Mazandaran province, 23-36 March over south west and west areas and 30 March-1 April, mostly over west and south west areas (mostly in river flooding form). The heavy rainfall events caused 140 river flooding from twelve watersheds and various floods were observed in seven basin areas including Caspian Sea, Persian GulfOman Sea, Urmia Lake, Ardestan-Yazd-Kerman, Qaraqorum Desert, Hamun and Salt Lake. During the first period, Qarahsu and Gorganrood river basins faced heavy rainfall during mid-March of 2019, so that according to meteorological data 74-354 mm of rain fell in different parts of the Golestan province almost continuously for five days and nights. The average rainfall in the Gorganrood basin was estimated at $150 \mathrm{~mm}$. The volume of rainfall has been more than 2.2 billion cubic meters in Gorganrood basin and above Aqqala city. On the other hand, the volume of runoff caused by this rainfall is estimated at 327 million
Fig. 1 Flooding cases in Iran increasing from 1951 to 2017

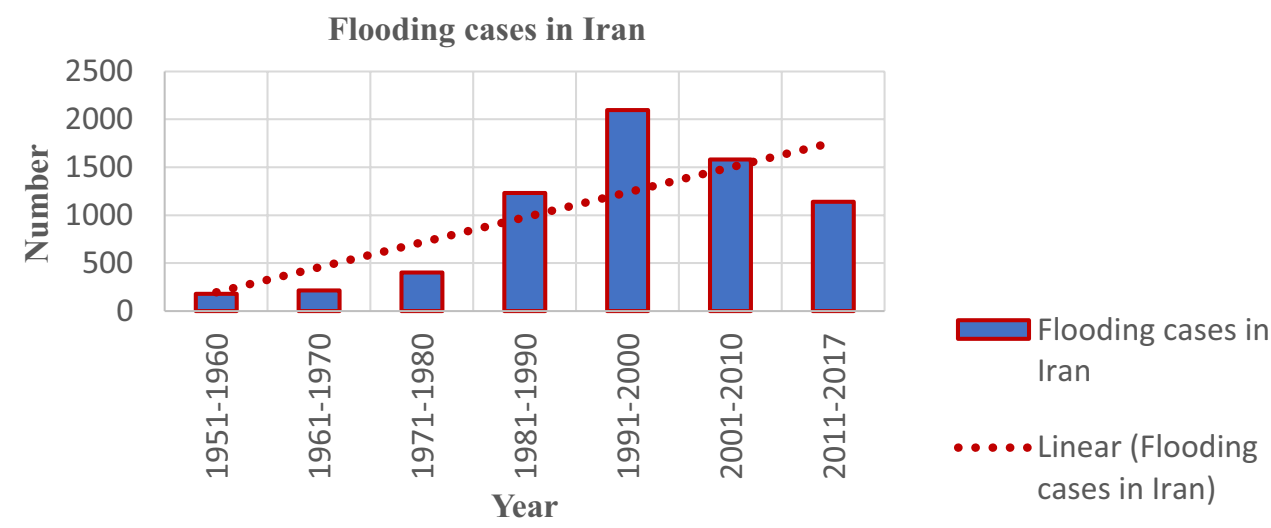


cubic meters which was reported by Iran Water Resource Management Company. During the second period, on March 24, 2019, only in Shiraz city, the intensity of 15-min thundershowers was recorded at $76 \mathrm{~mm}$ per hour which was unprecedented during a long-term statistical period (51 years). It was almost 1.8 times the maximum intensity of a 15 -min rainfall occurring in the last 15 years. The rainfall on the fifth day totaled $9.26 \mathrm{~mm}$, which was 9 times the long-term average rainfall of the same day. Also, the first weather system entered the country of Iran from the west during the days of March 24-30, 2019 and caused heavy rain showers and canal and river flooding. This flood was accompanied by many damages in Kohgiluyeh and Boyer-Ahmad, Chaharmahal and Bakhtiari and Ilam, especially Lorestan provinces reported by Iran national flood of 2019 report. Also, the weather system caused a maximum daily precipitation of $187.8 \mathrm{~mm}$ at Koohrang Station in Chahar Mahal-Bakhtiari province. The total amount of precipitation during March 17-31 was recorded $~ 28 \%$ of total annual Iran precipitation. The western Iran provinces and the northern provinces in the southern part of Caspian Sea have reported at around $30-60 \%$ of the total annual rainfalls during mid-late March 2019. The amount of rainfall in Lorestan province from March 26 to April 1, 2019 was recorded $314 \mathrm{~mm}$, which is equivalent to $57 \%$ of normal rainfall in one year. During the case of April 4-7, the average amounts of rainfall in the basin of "Dez" dam, basin of Karun river dam and in the basin of Karkheh dam were recorded $168 \mathrm{~mm}, 99 \mathrm{~mm}$ and $87 \mathrm{~mm}$, respectively. During March 24-27, 2019, the average rainfall amounts of Dez, Karun and Karkheh dam basins were recorded at $111 \mathrm{~mm}$, $35 \mathrm{~mm}$ and $108 \mathrm{~mm}$, respectively. The total rainfall in the first month of spring 2019 in Karun Bozorg and Karkheh basin was recorded equal to $234 \mathrm{~mm}$ and $223 \mathrm{~mm}$, respectively. The highest amount of precipitation occurred in Karkheh dam basin in the southeastern regions of the basin and in Nurabad and Poldakhtar stations, at around 340 and 320 mm, respectively. In the Greater Karun Basin, however, in the last two consecutive waves of rainfall, the Greater Karun received $175 \mathrm{~mm}$ of rainfall, in other words, the magnitude of this recent event was about 1.2 times that of the largest event in the last five decades. During this time Karkheh received $179 \mathrm{~mm}$, which is 1.5 times the largest event in the last five decades. The peak discharge of the flood entering at Karkhe's dam in Khuzestan province was recorded at $8400 \mathrm{~m}^{3} \mathrm{~s}^{-1}$, in the area of Dez $6700 \mathrm{~m}^{3}$ $\mathrm{s}^{-1}$ were measured and at Karun branch (before connecting to the Dez branch and assuming the absence of dams) discharge was recorded about $5000 \mathrm{~m}^{3} \mathrm{~s}^{-1}$.

Iran map which shows the observed total precipitation including the most severe floods which affected the provinces of Golestan, Fars, Khuzestan and Lorestan, during March-April 2019, is presented in Fig. 2. The highest precipitation (more than $200 \mathrm{~mm}$ ) has been recorded in the south part of Hamedan, south part of llam and south east part of Golestan provinces.

\section{Methodology and data collection}

This work uses the NCEP/NCAR datasets produced by the National Centers for Environmental Prediction/National Center for Atmospheric Research. The NCEP/NCAR reanalysis model is a global assimilation model for the surface land, buoy, satellite and other data fields resulted in the atmospheric data fields. The NCEP monthly datasets [19] are available from 1948 onwards. The model with a resolution of T62 $(209 \mathrm{~km})$ has 28 vertical sigma levels, and the results are accessible at $6 \mathrm{~h}$ intervals. The local ingestion process took only the $0 Z, 6 Z, 12 Z$ and $18 Z$ forecasted values, and therefore only those were used to make the monthly average and daily time series. Also, there are more than 80 different variables in several different coordinate systems, for example, 17 pressure level at 2.5 by $2.5^{\circ}$ grids, 11 isentropic level on 2.5 by $2.5^{\circ}$ grid and 28 sigma level on 192 by 94 Gaussian grids. So, this work examines the accessible historical archived model dataset by analysing climate normal to understand the mean pattern and anomaly shapes and then studies shifts and departures from climate normal values from 1981 to 2010 as a base, resulting from the World Meteorological Organization (WMO) Policy, which proposes using the latest period for the thirty-year normal. Studying the anomalies can designate climate change ability and make it expected to recognise the variations and anomaly constructions on the local and regional scale. Besides, the anomalies can give a reference border in more meaningful assessments between different regions. Also, the results can be more precise in the trends calculations. The composite mean and anomaly maps for this study were formed with the NOAA/ERSL Physical Sciences Division (www.ersl.noaa. gov/psd) support. Mean composites were considered as the variable average over the two months of March and April, and the anomalies were calculated as the monthly average's departure from the climatological normal mean (1981-2010). Here, climate normal and anomalies for the meteorological datasets such as mean sea level pressure, geopotential heights at $500 \mathrm{~h} \mathrm{~Pa}$, surface temperatures, relative humidity, precipitation rate, surface wind vector, $250 \mathrm{hPa}$ wind vector and meridional winds are used due to the inspection of the abnormal extreme weather patterns associated with the recent widespread flash floods in Iran. The monthly average of the climatological data has been analysed for the study period (March-April 2019). The precipitation model datasets are created based on the monthly global precipitation project (GPCP). 


\section{Accumulated Precipitation over the Provinces of I.R.Iran} 2019/03/17 - 2019/04/01

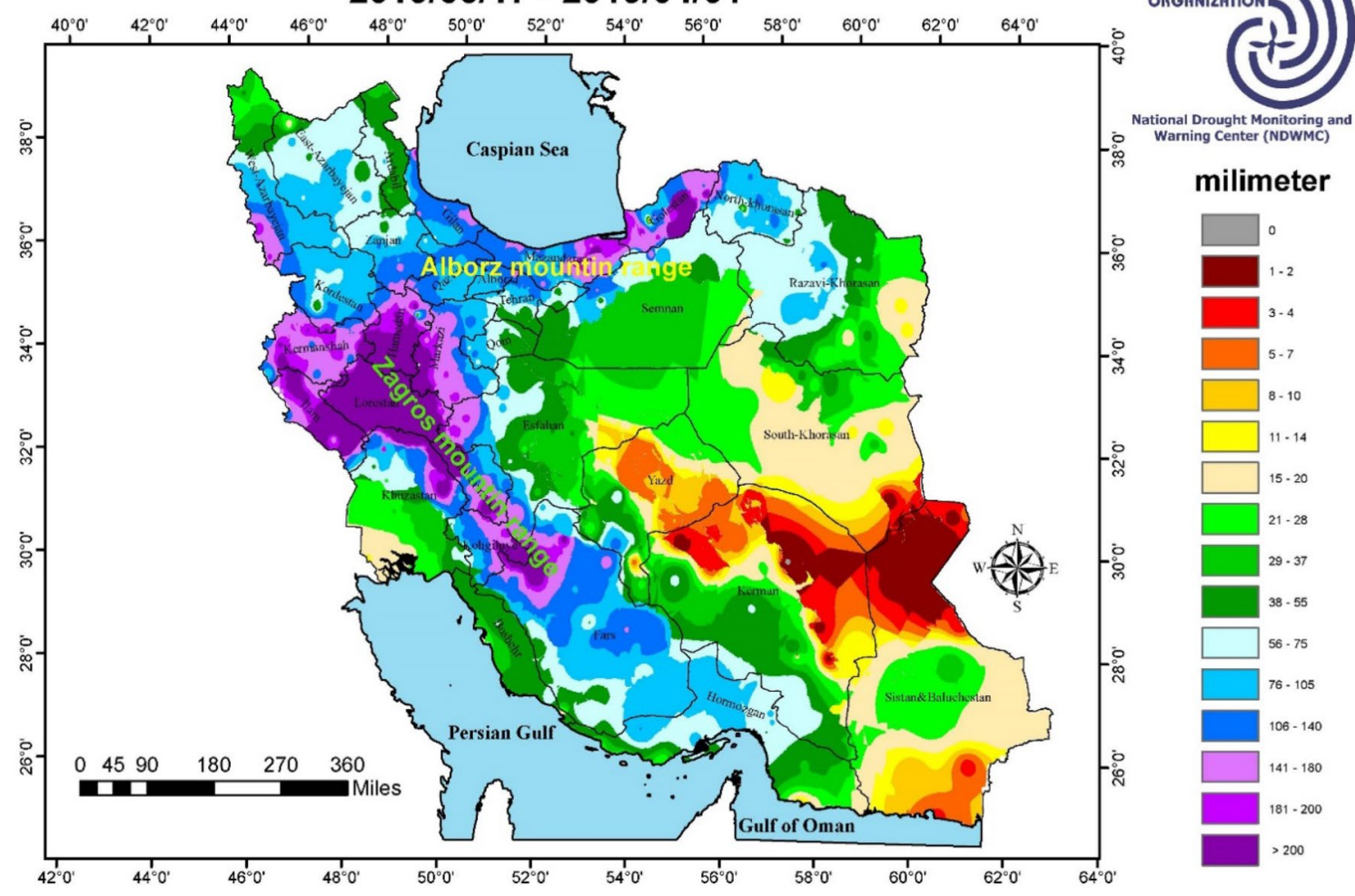

Fig. 2 Observed total precipitation during March-April 2019 (figure was reported from National Drought Monitoring and Warming Center of Iran Meteorological Organization)

\section{Time series of yearly seasonal mean values of surface temperature, geopotential height at $500 \mathrm{hPa}$ and precipitation rate}

Time series of the seasonal mean values including the regression analysis for annual mean surface temperature, geopotential height at $500 \mathrm{hPa}$ and precipitation rate from NCEP reanalysis model datasets from 1948 to 2019 for the study area are presented in Fig. 3. The figure shows that during 1948-2019 the surface temperature and $500 \mathrm{hPa}$ geopotential height have increased with a positive slope, whereas the precipitation rate has a negative slope over the study area in Iran.

\section{Climate normal and anomalies for mean sea level pressure (MSLP)}

The long-term (1981-2010) climate normal and anomalies for mean sea level pressure for March and April over the study area are presented in Fig. 4a, b. Figure 4c, d show the anomalies for the study period departure from the climate normal. The general pattern of the long-term normal mean for MSLP for March 2019 shows the northern high-pressure tongue is stretched from northern boundaries into the north-west, west and centre of Iran (isobar $1014.5 \mathrm{hPa}$ ). However, in the other part, the low-pressure system is dominated by an isobar tongue centred in the south-east of Iran (1013 hPa), whereas in April 2019 in spite of the same pattern as in March 2019, the northern prevalent high pressure has been weakened (centre of $1015 \mathrm{hPa}$ ), and the southern low pressure has been strengthened (centre of $1010 \mathrm{hPa}$ ) and extended further to the central areas. The anomaly map for March shows that pressures have been decreased in most part of study area with pressure gradient areas (PGA) mostly in the west and south west areas. The pressures have decreased over the northwest, central, south, north-east and east with a maximum negative change with a cell of $1.75 \mathrm{hPa}$. So, in the western areas, the pressure gradient has been increased which is noted in PGA (pressure gradient area) in Fig. 1c and which can be accompanied by increased instability. In April 2019, the MSLP has increased (weakening of the prevalent lowpressure system) mostly in west, south west and north east areas and did not change in the central areas. A comparison between the anomalies during March and April shows more pressure gradient during March rather than April mostly over west, south west and central parts of Iran. 

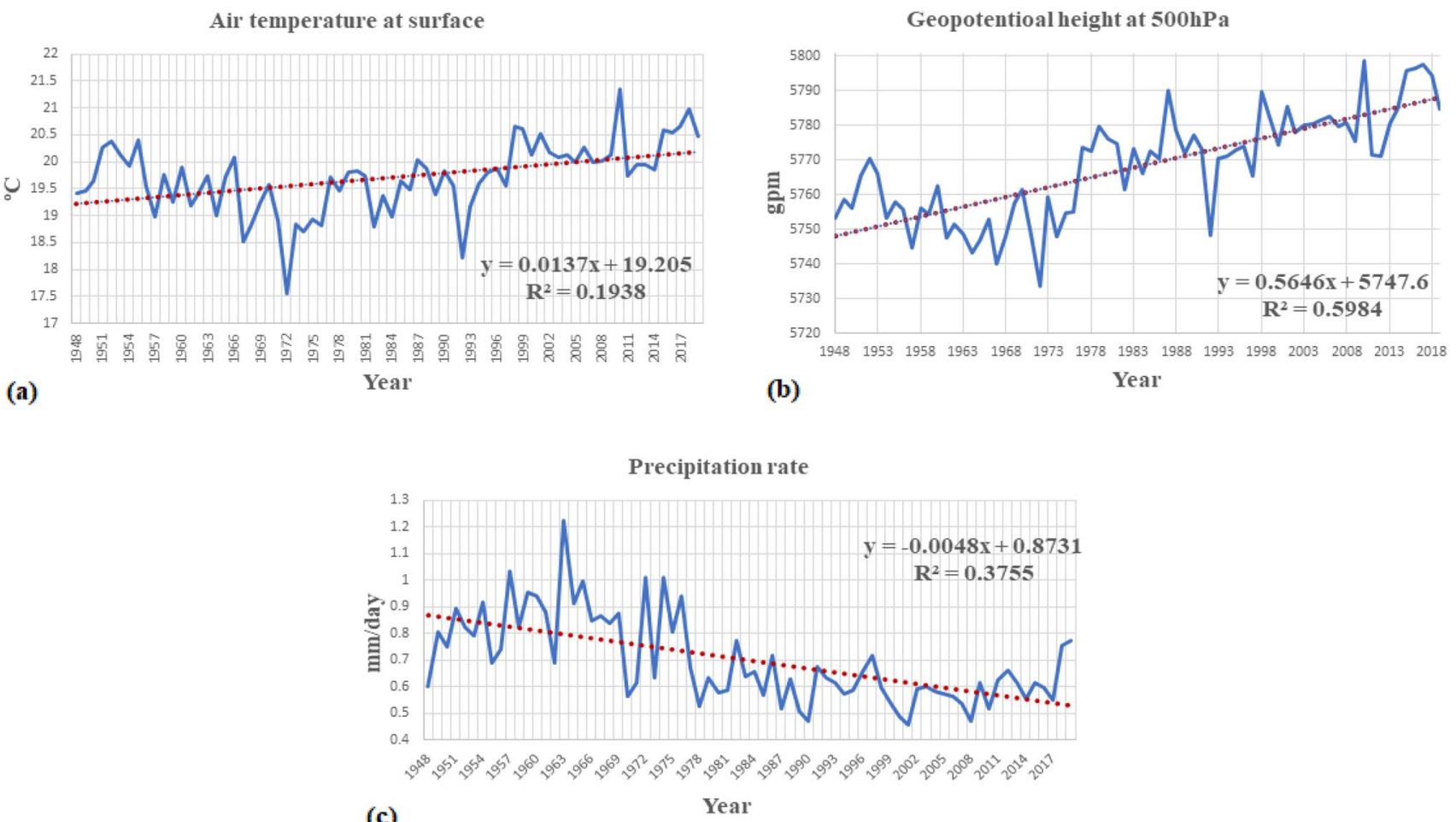

Fig. 3 Time series of the seasonal mean values including the regression analysis for annual mean surface temperature (a), geopotential height at $500 \mathrm{hPa}(\mathbf{b})$ and precipitation rate (c) from NCEP reanalysis model datasets from 1948 to 2019

\section{Climate normal and anomalies for $500 \mathrm{hPa}$ geopotential heights}

Long-term climatology mean for $500 \mathrm{hPa}$ for March and April over the study area is presented in Fig. $5 a, b$. The anomaly map with respect to climate normal is given in Fig. 5c, d. The normal mean maps for both months of March and April show westerly flows pattern, and the anomaly maps for both months show the strengthening and deepening of the mid-troposphere $500 \mathrm{hPa}$ heights with a centre of $40 \mathrm{gpm}$ over Iraq and the west part of Iran. The geopotential heights have decreased over all parts of Iran from 5 to $40 \mathrm{gpm}$ mostly in the west part and the change ranged from $-5 \mathrm{gpm}$ to $10 \mathrm{gpm}$ only over a small part of the south east area during the month of April. This is also along with the pressure gradient intensification Fig. 4c leading to the active weather system mostly during the month of March over the study period.

\section{Climate normal and anomalies for surface air temperature}

Long-term climatology mean for surface temperature for March and April over the study area is presented in Fig. 6a, b. This figure shows rather warmer surface air during April than March 2019 with almost the same pattern. The anomaly map with respect to climate normal is given in Fig. 6c, $\mathrm{d}$. The anomaly maps for the surface temperature during the study period show that the surface temperatures have been decreased (associated with lower 500 hpa geopotential heights) from $0.25^{\circ} \mathrm{C}$ to a maximum of around $3{ }^{\circ} \mathrm{C}$ in the east of Iraq and west of Iran. During March 2019, the cold air has been stretched from north-west to the west and south of Iran. The existence of the temperature contrast (rather warmer isotherms over the northern parts and rather colder tongue in the west and south west parts) can lead to instability. This accompanies with lower $500 \mathrm{hp}$ geopotential heights associated with rather colder air column. For example, in the south east of the Caspian Sea in Golestan province, the warmer surface temperature accompanies with rather colder atmosphere column. This may cause an increase in the locally (i.e., Golestan Province) unstable atmospheric condition. However, the study areas have been influenced by active frontal system during the study period. Also, in April 2019, the entire area of Iran has been colder than normal except a small part in the south east where no change is detected. 


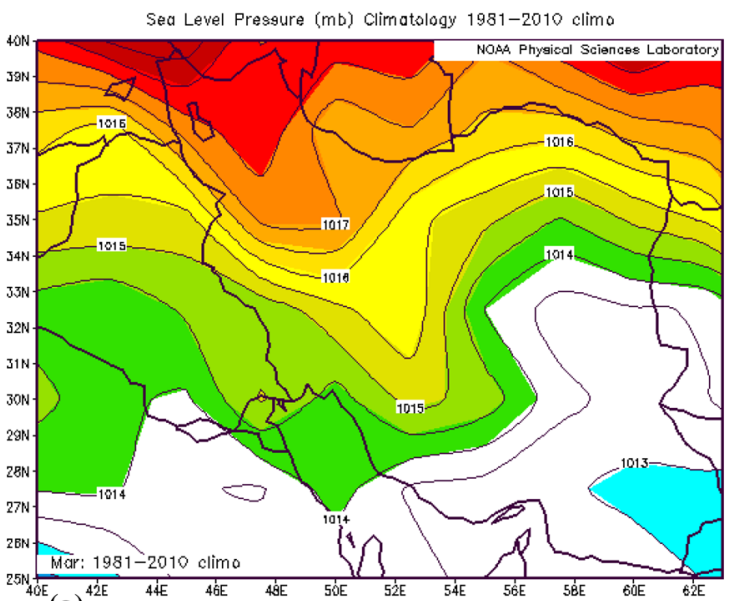

(a)

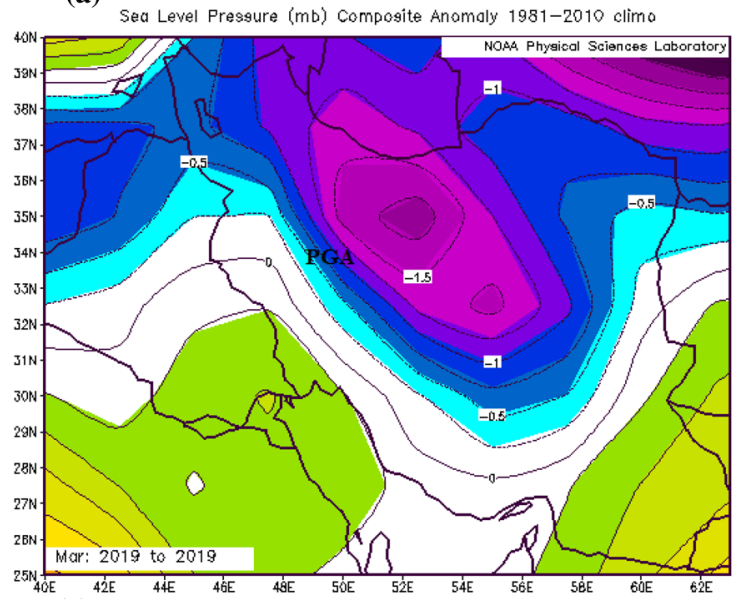

(c)
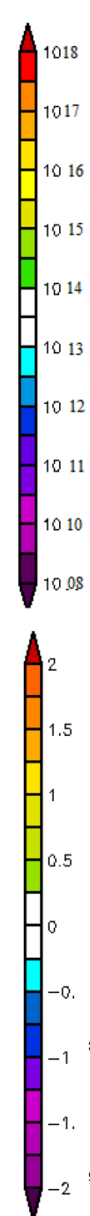

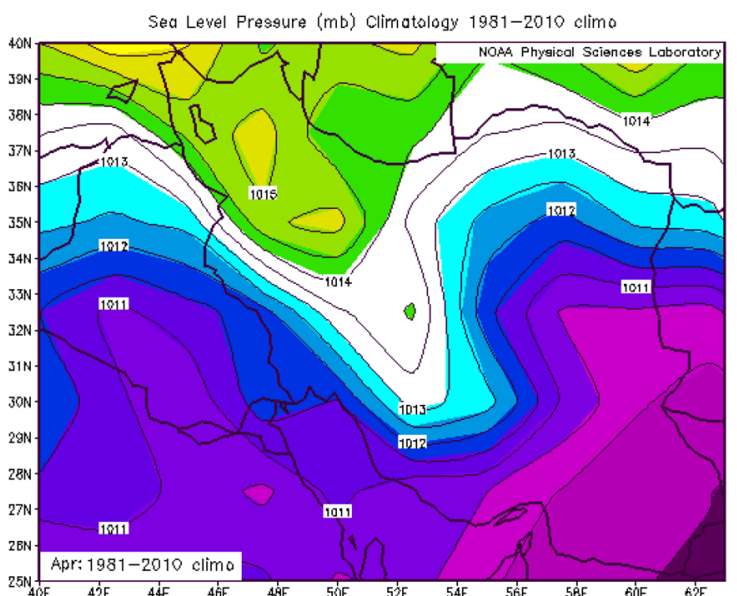

(b)

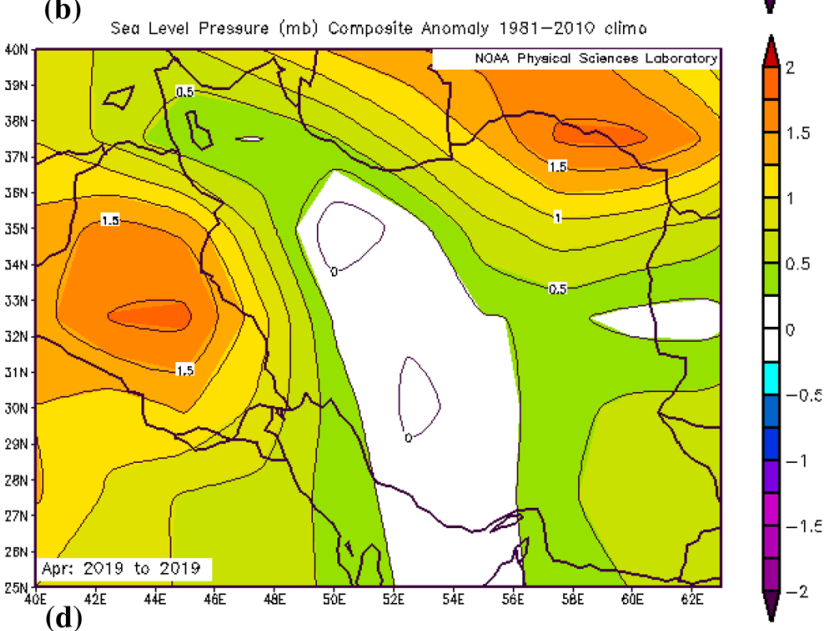

Fig. 4 Long-term normal climatology mean for MSLP (a and b) and anomalies (c and $\mathbf{d}$ ) for months of March and April 2019, respectively

\section{Climate normal and anomalies of $500 \mathrm{hPa}$ vertical velocities (omega)}

Long-term climate normal of $500 \mathrm{hPa}$ vertical velocity for months of March and April is presented in Fig. 7a and $\mathrm{b}$, and the anomaly maps for the same months during the study period relative to climate normal are shown in Fig. 7c, d. The anomaly maps show an intensification of abnormally strong vertical velocities associated with the active extreme weather system with a maximum difference at $-0.03 \mathrm{~Pa} / \mathrm{s}$ in month of March in the west, central and south east areas, whereas during the month of April, the maximum difference has been shifted to the eastern part of Iran. Since pressure decreases upward, a negative omega presents a rising motion, whereas a positive omega shows a subsiding motion.

\section{Climate normal and anomalies of precipitations}

Long-term climate normals of precipitation resulting from precipitation data in the Global Precipitation Climatology Project (GPCP) for months of March and April are presented in Fig. 8a, b. The composite anomaly maps during the study period are depicted in Fig. $8 c$, d. During the study period, there have been significant changes in the precipitation amounts mostly during March 2019 in the north-east, west, south-west and south of Iran with a maximum increase at around $120 \mathrm{~mm}$ in the west part of Iran associated with the extreme weather system. 

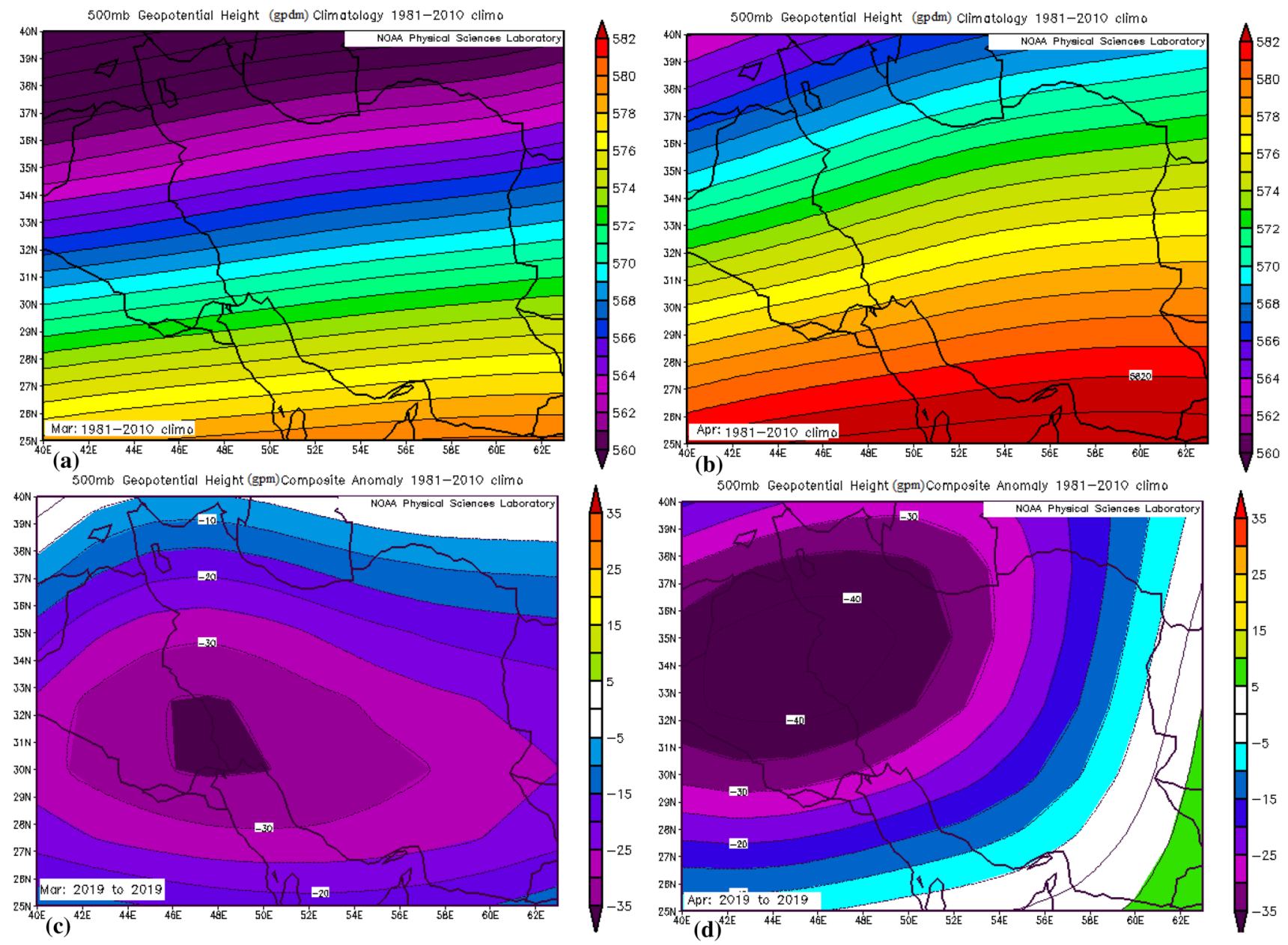

Fig. 5 Long-term normal climatology mean for $500 \mathrm{hPa}$ geopotential height (a and $\mathbf{b}$ ) and anomalies (c and $\mathbf{d}$ ) for months of March and April 2019, respectively

\section{Climate normal and anomalies of surface wind vectors}

Long-term climate normal of surface winds for months of March and April is presented in Fig. 9a, b and the composite anomaly maps during the study period are shown in Fig. 9c, d. Figure 9( $a$ and b) shows that the general pattern of the surface winds in the Oman sea and southern Iran is south-westerly (red arrow) whereas during the anomaly period Fig. 9c, d, the surface winds have abnormally changed into south easterlies. This is associated with rather warmer and more humid air mass flows from Oman sea and the Indian Ocean toward the study area. This leads to weather intensification when rather warmer and more humid air mass flows and interacts with rather dominant colder surface air mass over the study area (see Fig. 6c and d).

\section{Relative humidity vertical cross section anomalies}

Anomalies for the vertical cross section of the relative humidity are presented for months of March and April in Fig. 10a, b. As this figure shows the relative humidity has been increased mostly in the lower troposphere from $2 \%$ to $13 \%$ for month of March and 2-12\% for month of April 2019.

\section{Climate normal and anomalies of $250 \mathrm{hPa}$ wind vectors}

Long-term climate normal of $250 \mathrm{hPa}$ wind vectors for months of March and April is presented in Fig. 11(a, b), and the composite anomaly maps during the study 


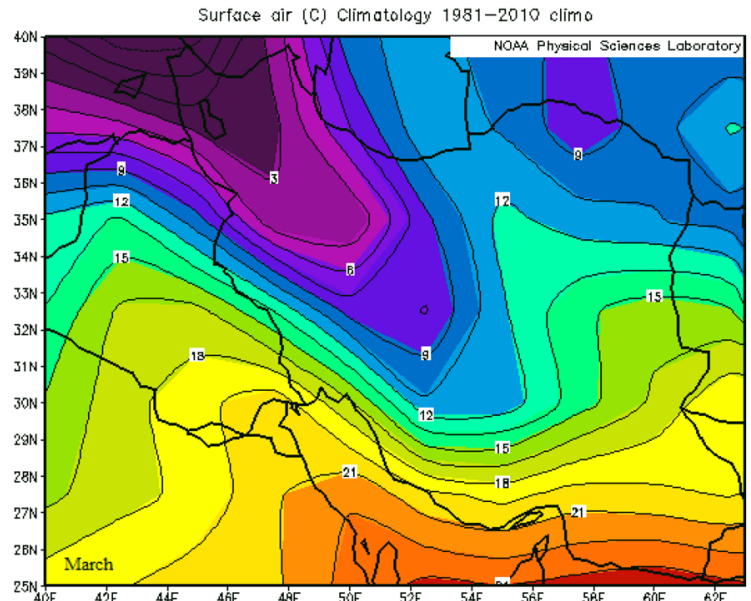

(a)

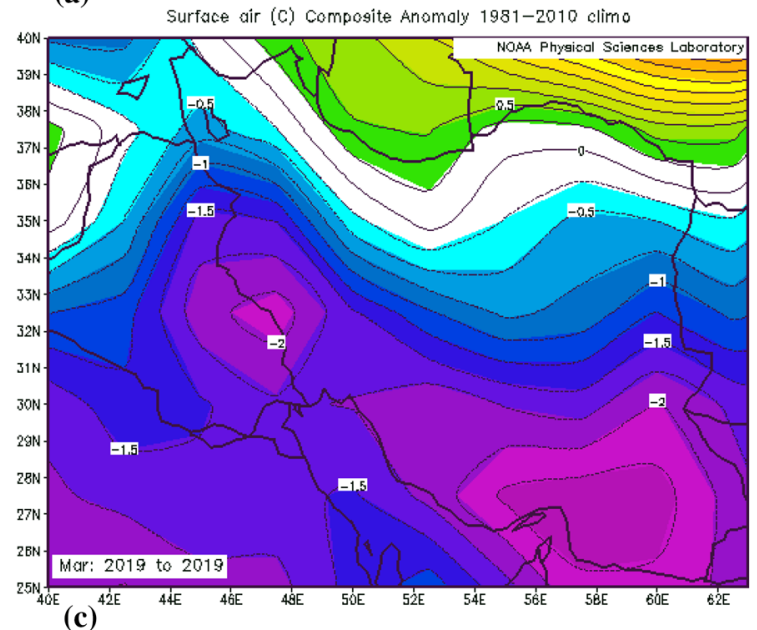

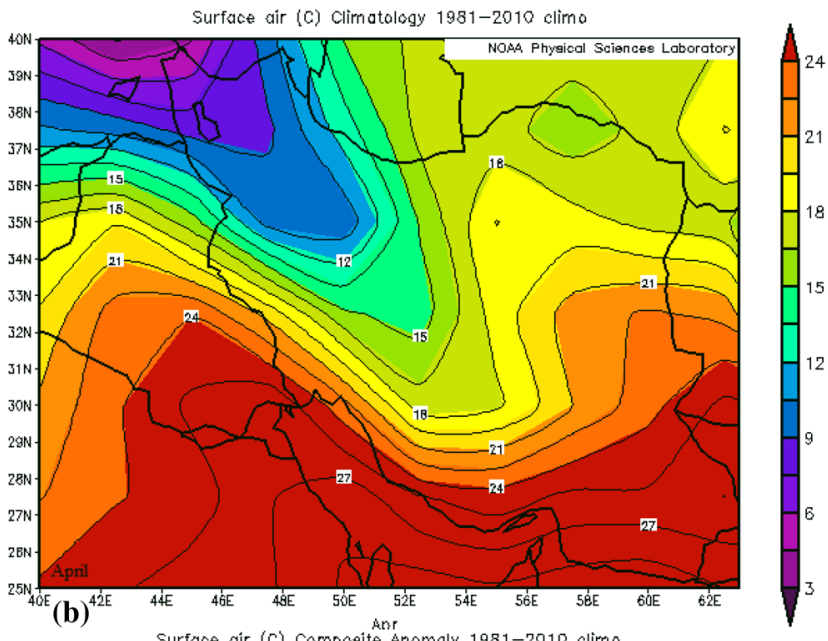
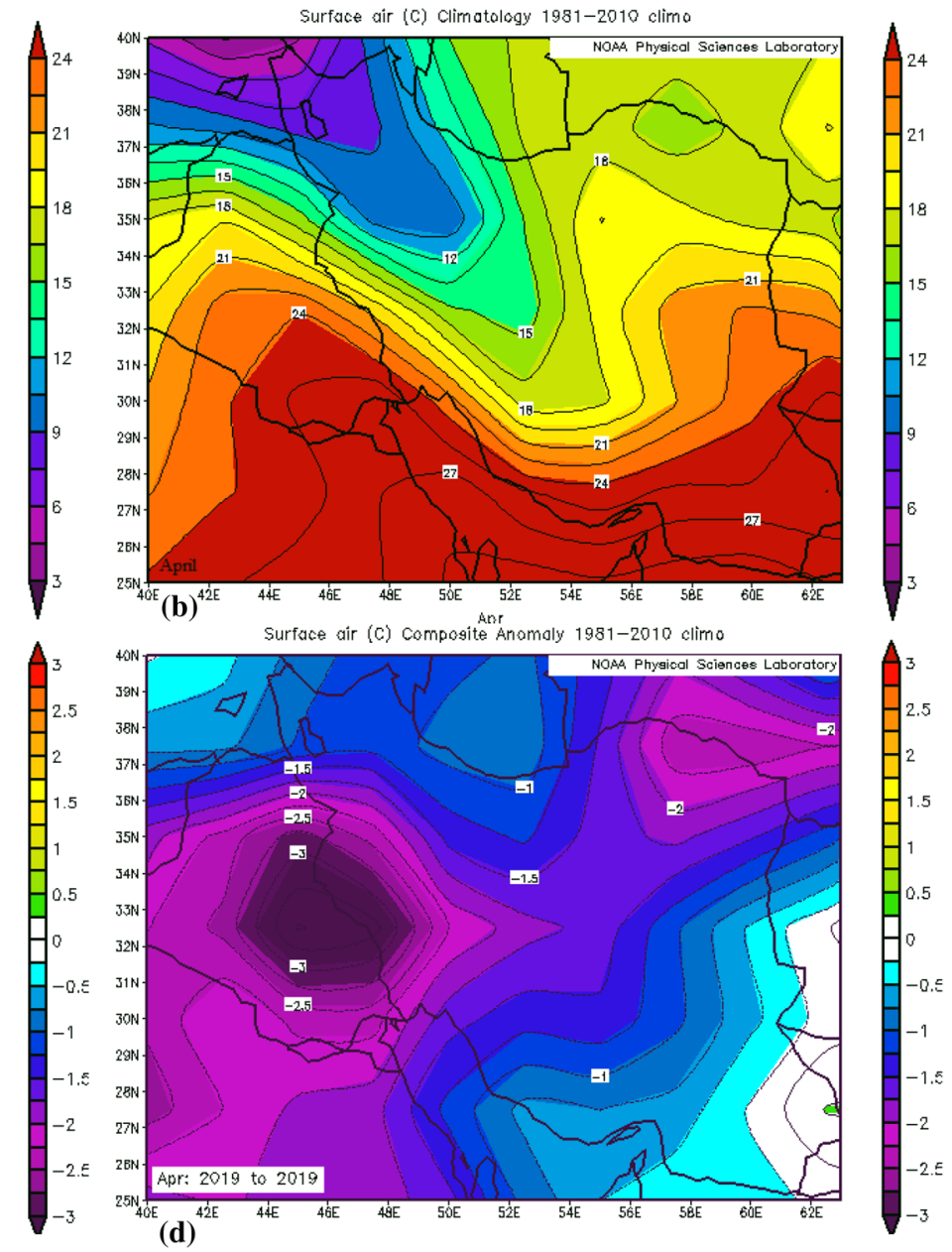

Fig. 6 Long-term normal climatology mean for surface temperature (a and b) and anomalies (c and d) for months of March and April 2019, respectively

period are shown in Fig. 11c, d. The climate normal map shows the location (crossing the Red sea) and intensifying (with the cores of $42 \mathrm{~m} / \mathrm{s}$ and $36 \mathrm{~m} / \mathrm{s}$ during March and April, respectively) of the westerly jet stream. During the study period, the jet has been intensified with the maximum around $12.5 \mathrm{~m} / \mathrm{s}$ during March and at around $11 \mathrm{~m} / \mathrm{s}$ during April in the east of the Red sea. During the study period, over the north-east side of the jet (in the study area), the abnormal cyclonic curvature has been developed, and then the westerlies flows have turned to the south-westerly and south wind flows. The red arrow shows the upper-tropospheric anomaly direction during the study period. When the jet stream turns to form a wavy pattern (jet meandering), the extreme weather tends to be shaped on the sides of ridges or troughs which have been amplified with higher amplitudes and rather slower motion. The results from the comprehensive climate models such as CMIP5 multimodels mostly forecast the poleward storm tracks shift due to climate change and global warming $[4,13,37]$.

\section{Vertical cross section of the meridional winds}

Figure 12 shows long term longitude-height cross section of the meridional wind for months of March (a) and April (b) and anomalies ( $c$ and d) during the study period averaged for latitudes $\left(25-40^{\circ} \mathrm{N}\right)$ where the longitudinal region is between $40^{\circ}$ and $63^{\circ} \mathrm{E}$. The anomalies figure for both March and April presents the abnormal vertical south flows over $\sim 50-63^{\circ} \mathrm{E}$ and the abnormal north vertical flows in $\sim 40-48^{\circ}$ E. Also, significant wind shear can be seen between them. The wind shear is defined as a rapid change in wind speed or/and direction. 


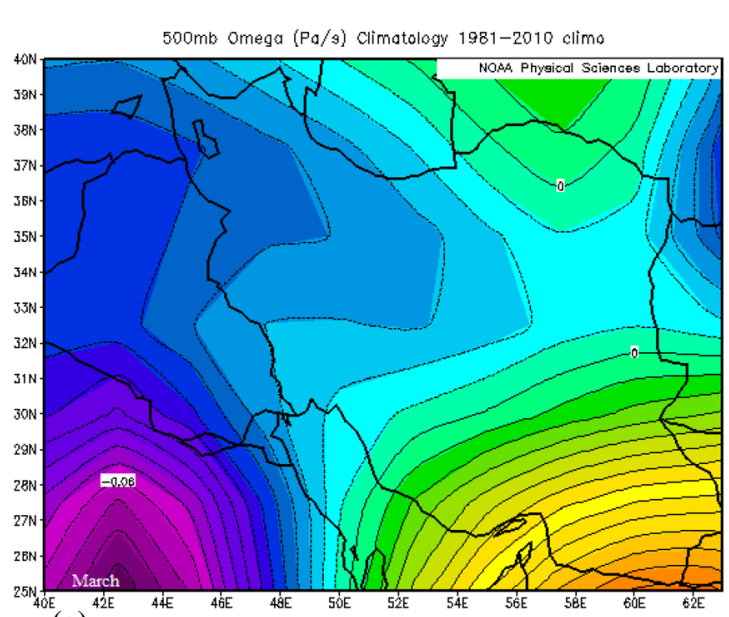

(a)

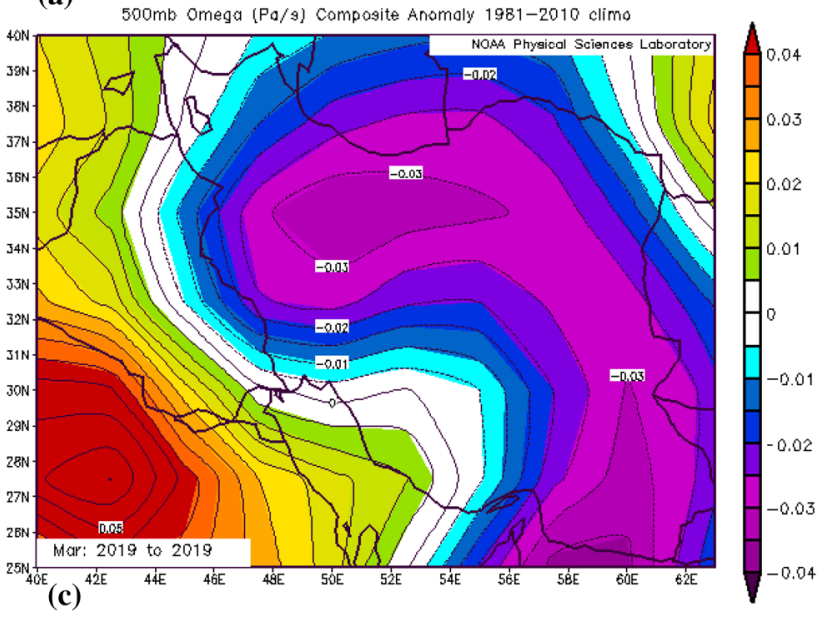

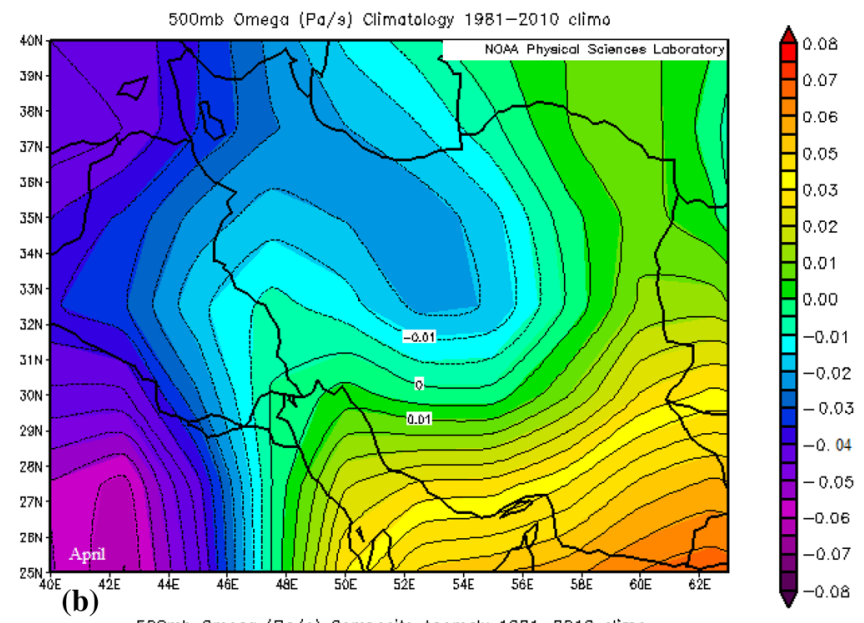

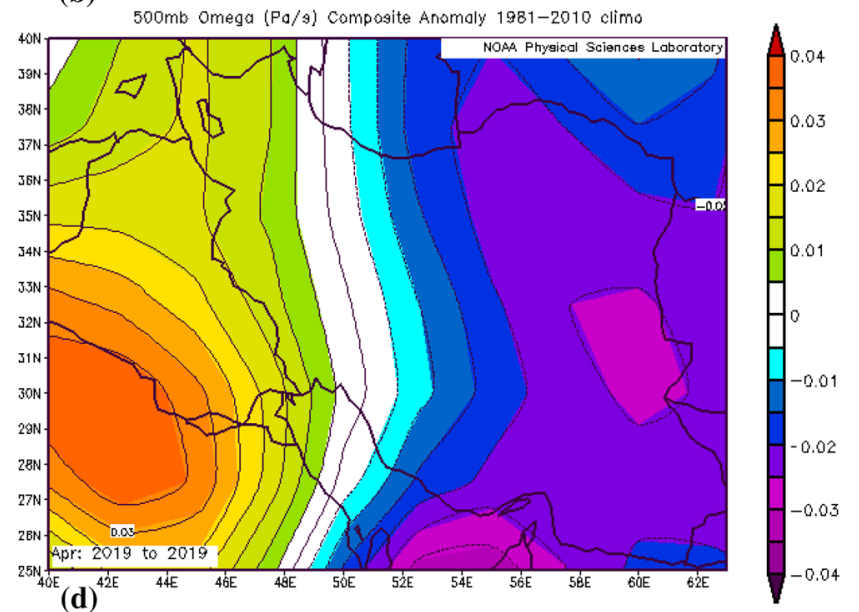

Fig. 7 Long-term normal climatology mean of 500 hPa omega for months of March (a) and April (b), 2019 and anomalies (c and d), respectively

\section{Summary and conclusions}

This work has revealed the existence of the abnormal weather pattern associated with the frontal system during March-April 2019 leading to the severe and devasting flooding events in Iran. This work has compared the climate normal and anomalies of the meteorological parameters by examining the NCEP/NCAR reanalysis datasets. This research has shown the occurrence of abnormal and intensified the active frontal weather systems during the study period over most of Iran with the increase in the pressure gradient, enhanced vertical motion along with strong $500 \mathrm{hPa}$ mid-tropospheric westerly currents. The relative humidity at $850 \mathrm{hPa}$ was on average $4-11 \%$ higher than the climatological normal mean. Also, the relative humidity has been increased from low level to upper levels along with rather regional colder surface air. However, two months before this disastrous flooding events, the regional surface air has been abnormally warmer $\sim 0.5-2{ }^{\circ} \mathrm{C}$ rather than the climate normal (the figure was not presented here), possibly caused by snow melting in the mountainous areas and higher runoff during the flash floods. The surface wind vector analysis has shown the intensification of the south flows originated from southern marine sources of Oman sea and the Indian Ocean during the study period providing warm and wet air mass sources encountered with regional colder surface air mass. Upper-level wind vectors at $250 \mathrm{hPa}$ and vertical profile of the meridional anomalies have displayed the abnormal jet meandering and significant vertical meridional wind shear as the signature of regional and global warming impact for more intensified weather formation over the study areas during the study period. So, this study shows that the mentioned flash flooding cases during March-April 2019 period in Iran can be possibly attributed to climate change. However, a more thorough understanding of changes in the short-time scale extreme events, particularly in climate variables such as temperature, precipitation and winds, needs long-term observational data of higher temporal resolution, such as daily or sub-daily. This has some limitation in many regions like Iran. 

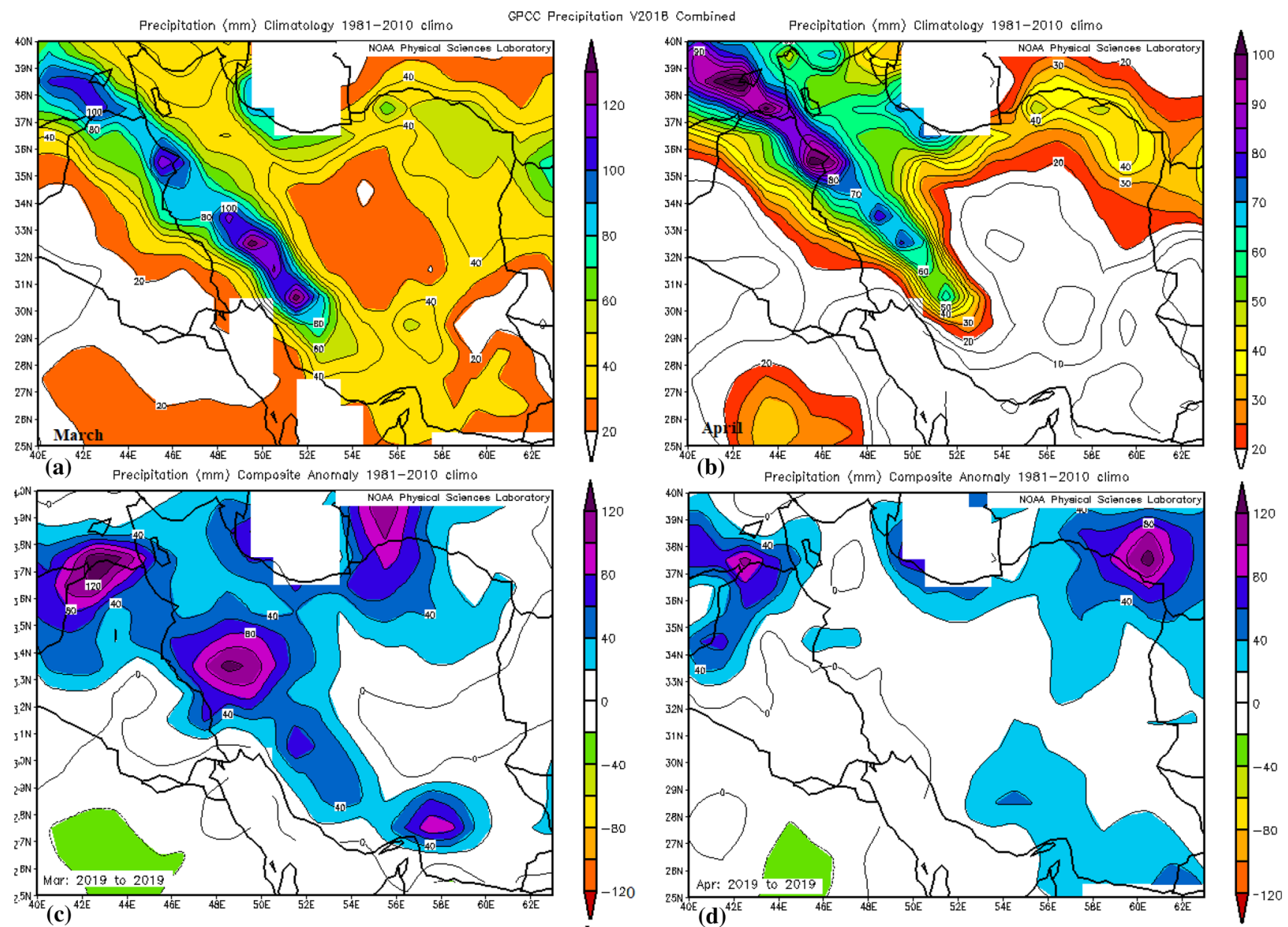

Fig. 8 Long-term normal climatology precipitations for months of March (a) and April (b) 2019 and anomalies (c and d), respectively 


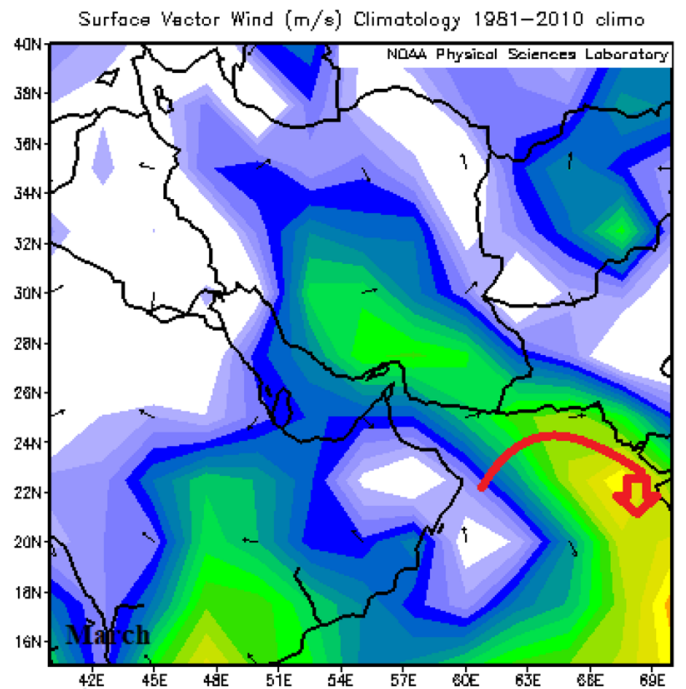

(a)

Surfaca Yeotor Wind (m/a) Compoaite Anomaly $1981-2010$ slimo

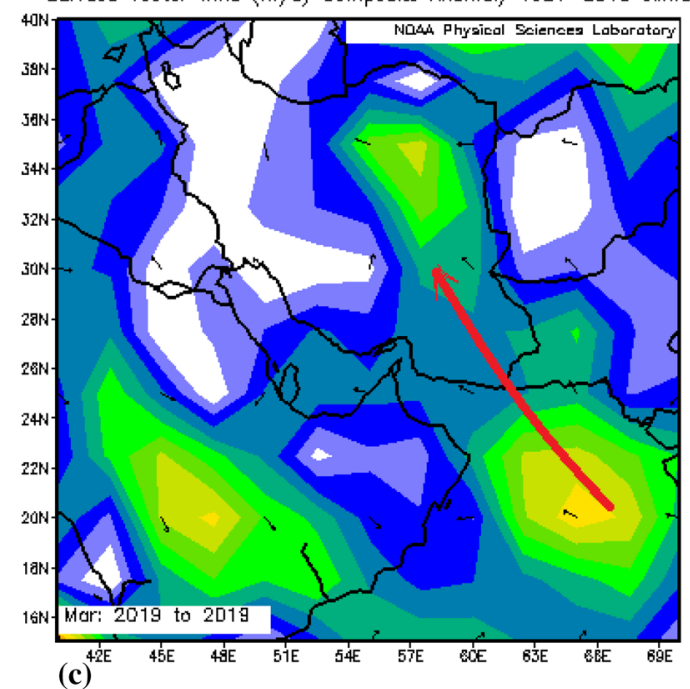

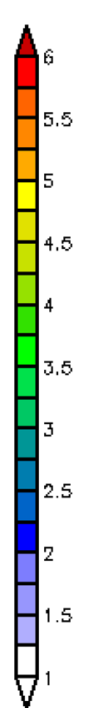

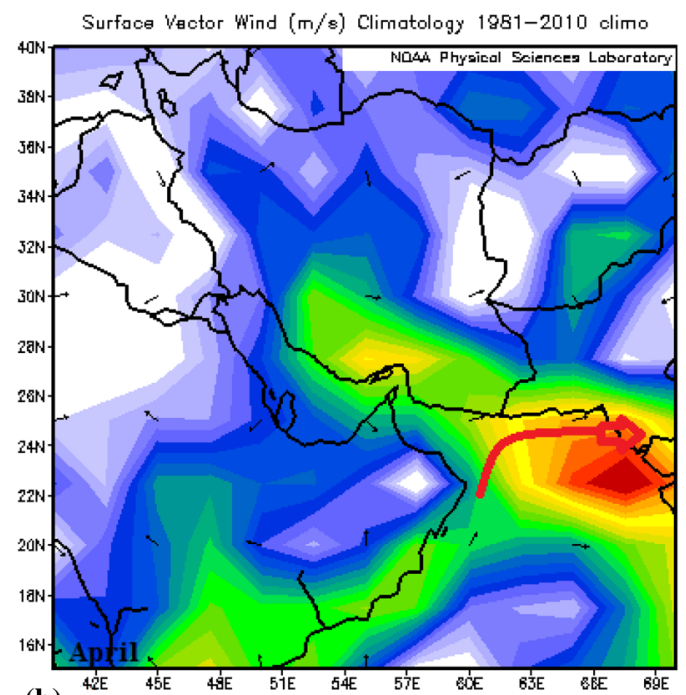

(b)
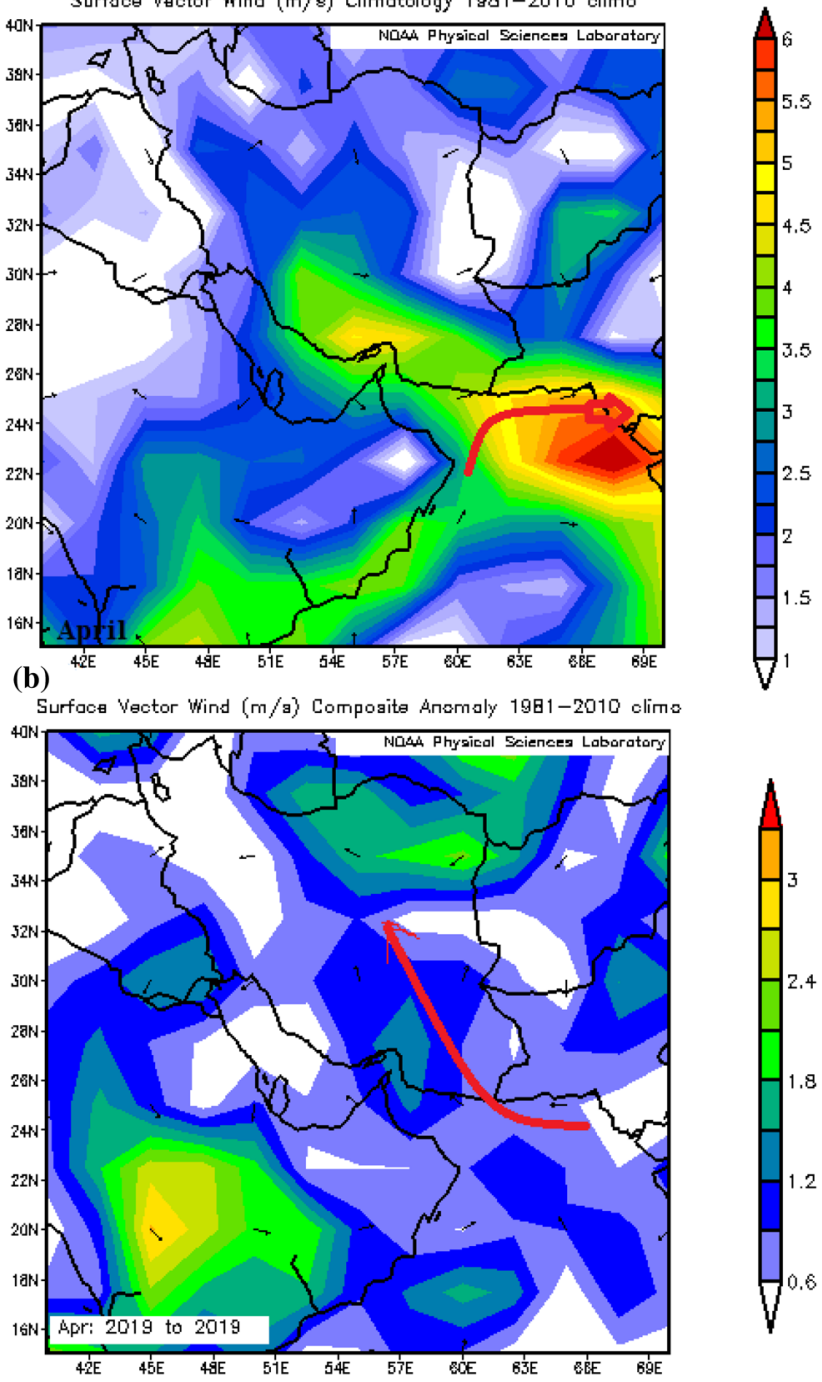

(d)

Fig. 9 Long-term normal climatology mean of surface wind vectors for months of March (a) and April (b) and anomalies (c and d), respectively 

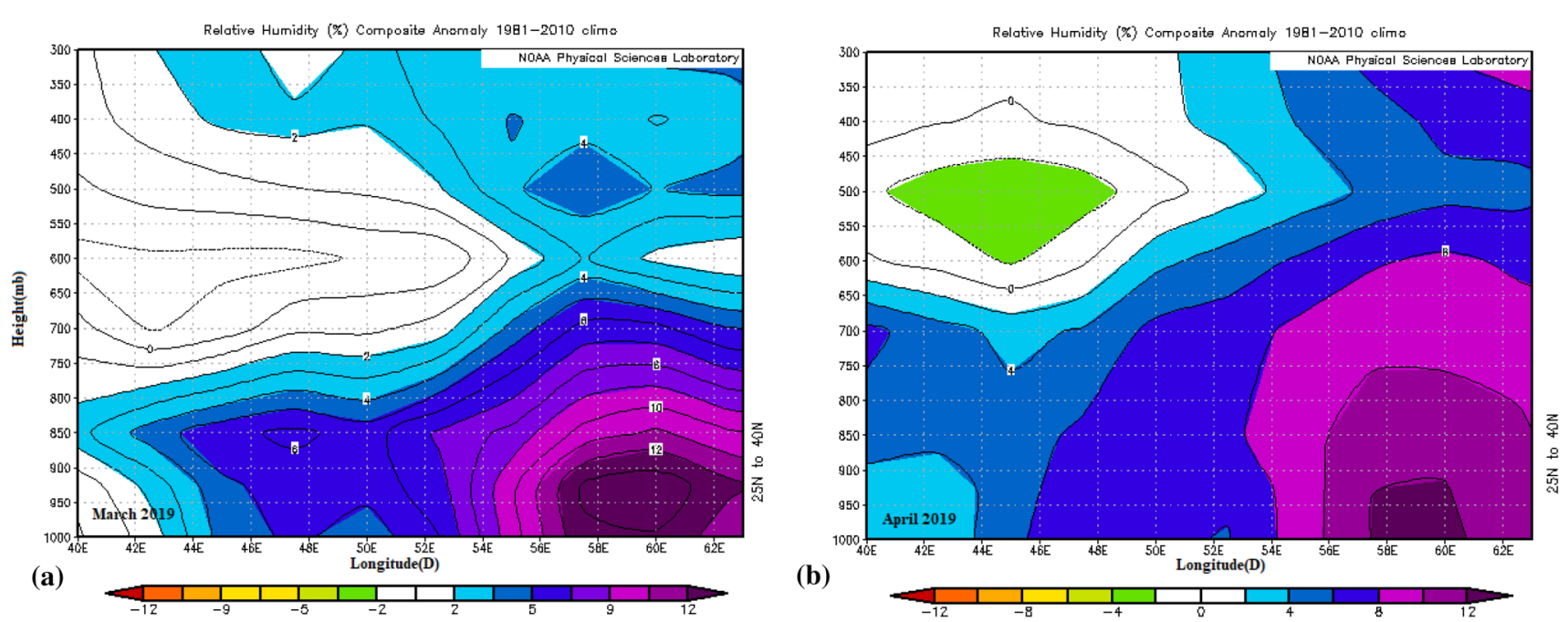

Fig.10 Anomalies of the relative humidity vertical cross section for months of March (a) and April (b) over the study area

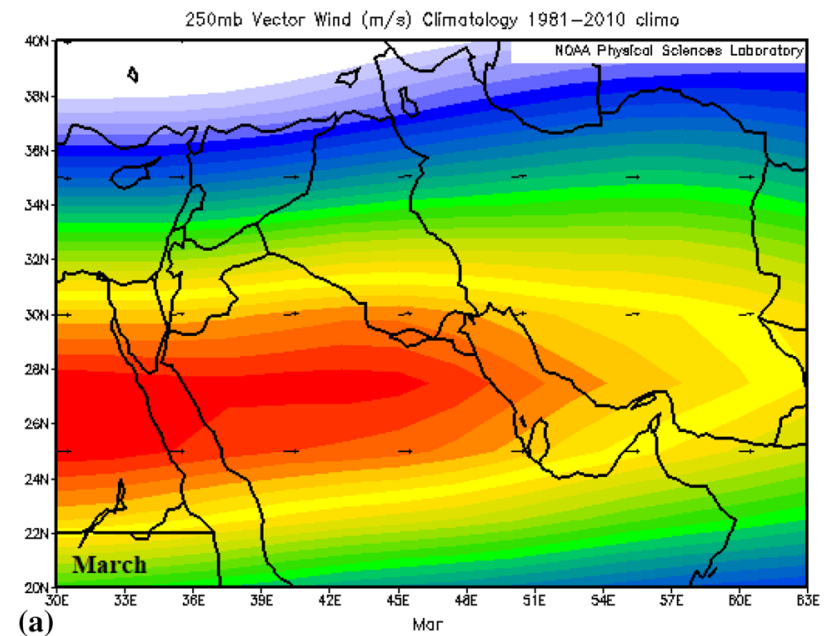

(a)
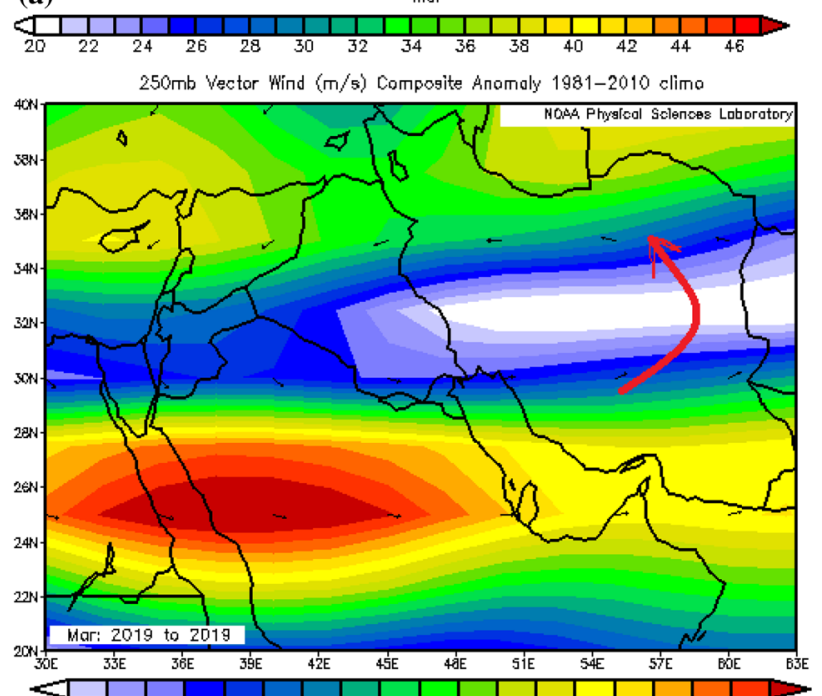

(c)
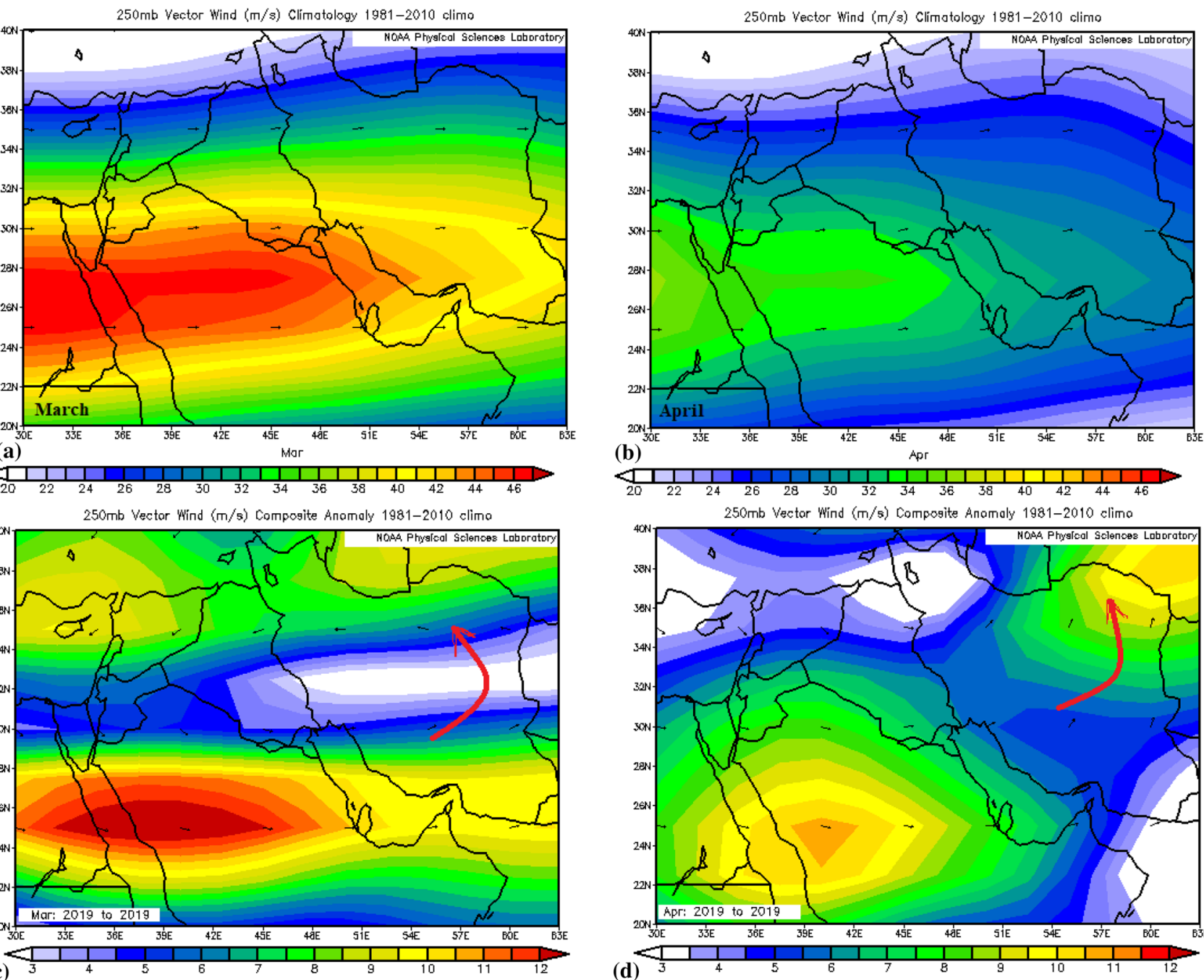

(b)
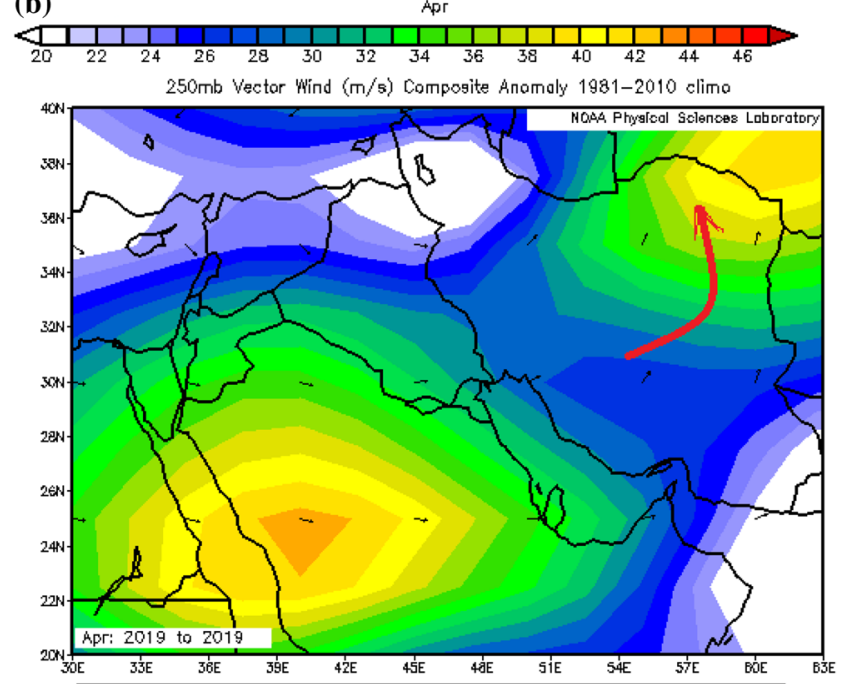

(d)

Fig. 11 Long-term normal climatology wind vectors at $250 \mathrm{hPa}$ for March (a) and April (b) and anomalies (c and d), respectively

\section{SN Applied Sciences}



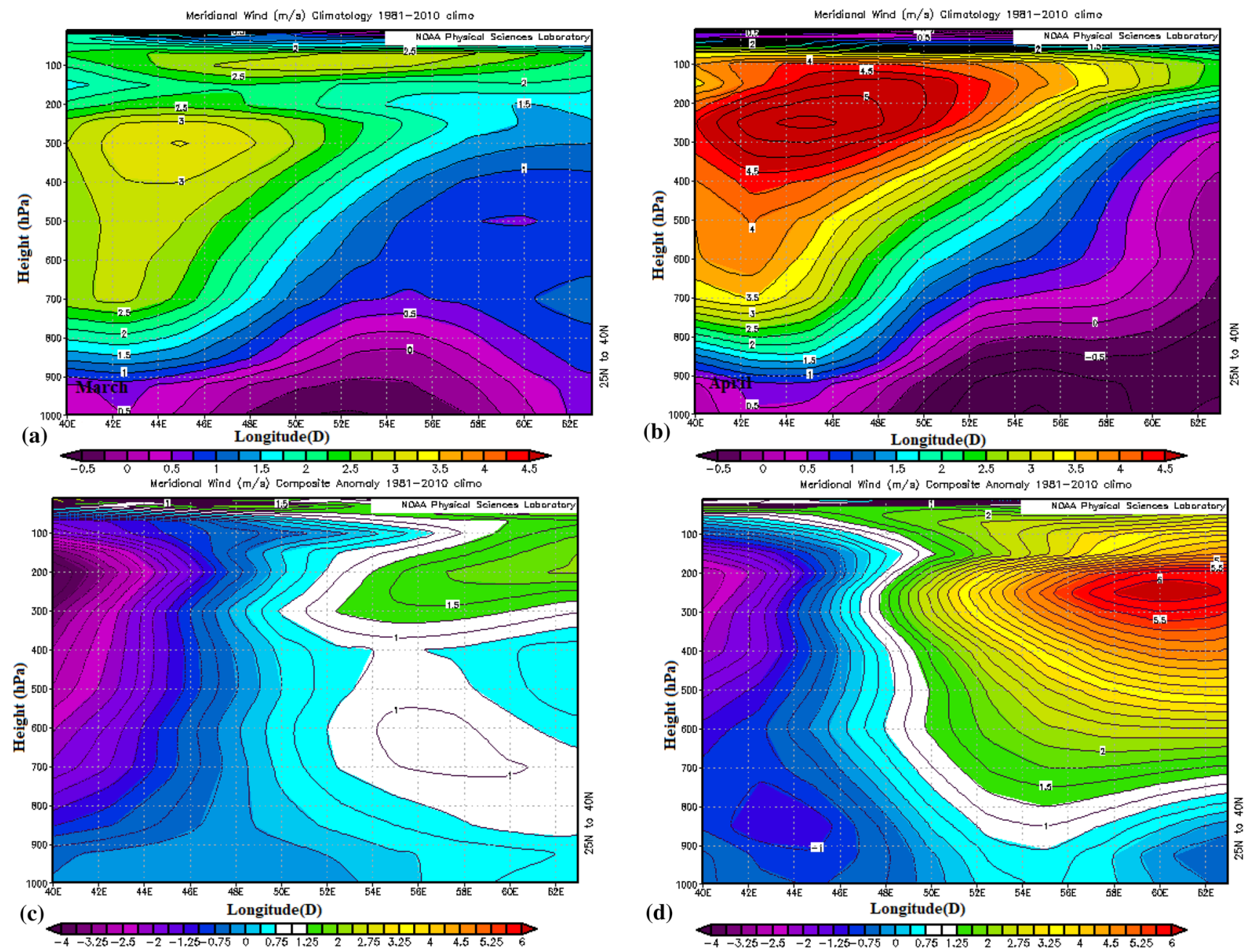

Fig. 12 Long-term normal mean ( $\mathbf{a}$ and $\mathbf{b}$ ) and anomalies (c and $\mathbf{d}$ ) of the meridional winds vertical cross section for months of March and April, respectively

Acknowledgements Thanks to NOAA/ESRL PSD, Physical Science Division, Boulder Colorado from their web site at http://www.esrl.noaa. gov/psd/. Thanks to Special Committee on the Iranian National Flood for the 2019 flood report and thanks to Iran Meteorological Organization and Iran water Resource Management Company for providing the required data. The author would like to thank the anonymous referees for their valuable comments.

\section{Compliance with ethical standards}

Conflict of interest The author declares that there is no conflict of interest to disclose.

\section{References}

1. Al-Maamary HM et al (2017) Climate change: the game changer in the gulf cooperation council region. Renew Sustain Energy Rev 76:555-576
2. Amiri MJ, Eslamian SS (2010) Investigation of Climate Change in Iran. J Environ Sci Technol 3(4):208-216. https://doi.org/10.3923/ jest.2010.208.216

3. Andersen TK, Marshall Shepherd J (2013) Floods in a changing climate. Geogr Compass 7(2):95-115. https://doi.org/10.1111/ gec3.12025

4. Barnes EA, Polvani L (2013) Response of the midlatitude jets, and of their variability, to increased greenhouse gases in the CMIP5 models. J Clim 26(18):7117-7135

5. Basha $G$ et al (2015) Long-term projections of temperature, precipitation and soil moisture using non-stationary oscillation processes over the UAE region. Int J Climatol 35(15):4606-4618

6. Borick CP, Rabe BG (2014) Weather or not? Examining the impact of meteorological conditions on public opinion regarding global warming. Weather, Clim Soc 6(3):413-424. https://doi. org/10.1175/wcas-d-13-00042.1

7. Borga M, Stoffel M, Marchi L, Marra F, Jakob M (2014) Hydrogeomorphic response to extreme rainfall in headwater systems: flash floods and debris flows. J Hydrol 518:194-205. https://doi. org/10.1016/j.jhydrol.2014.05.022

8. Bryndal T, Franczak P, Kroczak R, Cabaj W, Kołodziej A (2017) The impact of extreme rainfall and flash floods on the flood risk 
management process and geomorphological changes in small Carpathian catchments: a case study of the Kasiniczanka river (Outer Carpathians, Poland). Nat Hazards 88(1):95-120. https:// doi.org/10.1007/s11069-017-2858-7

9. Bronstert A (2003) Floods and climate change: interactions and impacts. Risk Anal 23(3):545-557. https://doi. org/10.1111/1539-6924.00335

10. Brooks J, Oxley D, Vedlitz A, Zahran S, Lindsey C (2014) Abnormal daily temperature and concern about climate change across the United States. Rev Policy Res 31(3):199-217. https ://doi.org/10.1111/ropr.12067

11. Brulle RJ, Carmichael J, Jenkins JC (2012) Shifting public opinion on climate change: an empirical assessment of factors influencing concern over climate change in the U.S., 20022010. Clim Change 114(2):169-188. https://doi.org/10.1007/ s10584-012-0403-y

12. Capstick SB, Pidgeon NF (2014) Public perception of cold weather events as evidence for and against climate change. Clim Change 122(4):695-708. https://doi.org/10.1007/s1058 4-013-1003-1

13. Chang, Edmund K., et al. (2012) CMIP5 multimodel ensemble projection of storm track change under global warming. Journal of Geophysical Research: Atmospheres, 117 (23)

14. Cheshmehzangi A (2020) The analysis of global warming patterns from 1970s to 2010s. Atmos Clim Sci 10(03):392-404. https ://doi.org/10.4236/acs.2020.103022

15. Droogers P et al (2012) Water resources trends in middle east and North Africa towards 2050. Hydrol Earth Syst Sci 16(9):3101-3114

16. Fazel-Rastgar F (2020) Contribution of deforestation to severe flooding in southeast parts of the Caspian Sea: a case study with NDVI analysis. J Extreme Events. https://doi.org/10.1142/s2345 737620500086

17. Gaume E, Bain V, Bernardara P, Newinger $O$, Barbuc $M$, Bateman A, Viglione A (2009) A compilation of data on European flash floods. J Hydrol 367(1-2):70-78. https://doi.org/10.1016/j.jhydr ol.2008.12.028

18. Hoegh-Guldberg $O$, Jacob $D$, Taylor $M$, Guillén Bolaños $T$, Bindi M, Brown S, Zhou G (2019) The human imperative of stabilizing global climate change at $1.5^{\circ} \mathrm{C}$. Science 365:6459-6974. https:// doi.org/10.1126/science.aaw6974

19. Kalnay E et al (1996) The NCEP/NCAR 40-year reanalysis project. Bull Am Meteor Soc 77(3):437-471

20. Karami N (2019) The modality of climate change in the middle east: drought or drying up? J Interrup Stud 2(1):118-140

21. Lang C (2014) Do weather fluctuations cause people to seek information about climate change? Clim Change 125(3-4):291303. https://doi.org/10.1007/s10584-014-1180-6

22. Lelieveld J et al (2013) Model projected heat extremes and air pollution in the eastern Mediterranean and Middle East in the twenty-first century. Reg Environ Change 14(5):1937-1949

23. Modarres R, Sarhadi A, Burn DH (2016) Changes of extreme drought and flood events in Iran. Glob Planet Change 144:6781. https://doi.org/10.1016/j.gloplacha.2016.07.008
24. MODIS web (n.d.) Retrieved from https://modis.gsfc.nasa.gov/ gallery/individual.php?db_date $=2019-03-31$

25. Nearly 1 million children affected by massive floods in Iran (n.d.) Retrieved from https://www.unicef.org/press-releases/nearly-1millionchildren-affected-massive-floods-iran

26. "Near-term Climate Change: Projections and Predictability." Climate Change 2013 - The Physical Science Basis, pp. 953-1028

27. Önol B et al (2013) Evaluation of the twenty-first century RCM simulations driven by multiple GCMs over the Eastern Mediterranean-Black Sea region. Clim Dyn 42(7-8):1949-1965

28. Ozturk T et al (2015) Projections of climate change in the Mediterranean basin by using downscaled global climate model outputs. Int J Climatol 35(14):4276-4292

29. Papagiannaki K, Lagouvardos K, Kotroni V, Bezes A (2015) Flash flood occurrence and relation to the rainfall hazard in a highly urbanized area. Nat Hazards Earth Syst Sci. https://doi. org/10.5194/nhess-15-1859-2015

30. Rudman LA, McLean MC, Bunzl M (2013) When truth is personally inconvenient, attitudes change. Psychol Sci 24(11):22902296. https://doi.org/10.1177/0956797613492775

31. Saboohi R et al (2012) Trend analysis of temperature parameters in Iran. Theoret Appl Climatol 109(3-4):529-547

32. Seneviratne, S.I., N. Nicholls, D. Easterling, C.M. Goodess, S. Kanae, J. Kossin, Y. Luo, J. Marengo, K. Mclnnes, M. Rahimi, M. Reichstein, A. Sorteberg, C. Vera, and X. Zhang, (2012) Changes in climate extremes and their impacts on the natural physical environment. In: Field CB, V Barros, TF Stocker, D Qin, DJ Dokken, KL Ebi, MD Mastrandrea, KJ Mach, G-K Plattner, SK Allen, M Tignor, and PM Midgley (eds). Managing the Risks of Extreme Events and Disasters to Advance Climate Change Adaptation: A Special Report of Working Groups I and II of the Intergovernmental Panel on Climate Change (IPCC). Cambridge University Press: Cambridge 109-230

33. Sharifi F, Samadi SZ, Wilson CA (2012) Causes and consequences of recent floods in the Golestan catchments and Caspian Searegions of Iran. Nat Hazards 61(2):533-550. https://doi. org/10.1007/s11069-011-9934-1

34. Spence A, Poortinga W, Butler C, Pidgeon NF (2011) Perceptions of climate change and willingness to save energy related to flood experience. Nat Clim Change 1(1):46-49. https://doi. org/10.1038/nclimate1059

35. Trenberth KE (2008) The impact of climate change and variability on heavy precipitation, floods, and droughts. Encycl Hydrol Sci. https://doi.org/10.1002/0470848944.hsa211

36. Vaghefi SA et al (2019) Author correction: the future of extreme climate in Iran. Sci Rep 9(1):1-11

37. Vallis GK et al (2014) Response of the large-scale structure of the atmosphere to global warming. Q J Royal Meteorol Soc 141(690):1479-1501

Publisher's Note Springer Nature remains neutral with regard to jurisdictional claims in published maps and institutional affiliations. 